\title{
FINDING WAYS TO IMPROVE EMPLOYEE PERFORMANCE IN BANKING SECTOR
}

\author{
Ahyar Yuniawan \\ Fakultas Ekonomika dan Bisnis, Universitas Diponegoro, Semarang \\ Email : ahyar_yuniawan@yahoo.com \\ Eldes Willy Filatrovi \\ Sekolah Tinggi Ilmu Ekonomi, BANK BPD JATENG, Semarang \\ Email : eldeswillyfilatrovi@stiebankbpdjateng.ac.id \\ Khoirul Attiq \\ Sekolah Tinggi Ilmu Ekonomi, BANK BPD JATENG, Semarang \\ Email : khoirul.attiq@gmail.com
}

Received: May 2020; Accepted: July 2020; Available online: July 2020

\begin{abstract}
The purpose of this research is to investigate the effects of individual characteristics and intrinsic motivation on innovative behaviour and employee performance, and the effect innovative behaviour on employee performance. The study was conducted at banking company, the sample size is about 200 employees. Methods of data analysis used in this study is a quantitative analysis method where quantitative data analysis method is a method of analysis in the form of figures and calculations using statistical methods. In simplify the analysis process, will be used Structural Equations Modeling (SEM). According to the analysis, it is concluded as the followings: individual characteristics has a positive effect oninnovative behaviour; intrinsic motivation has a positive effect on innovative behaviour; individual characteristics has a positive effect on employee performance intrinsic motivation has a negative effect on employee performance and innovative behaviour has apositive effect on employee performance. The results of this study and the limitations found to be a source of ideas and input for the development of this study in the future, the suggested expansion of this research include: Future research is not only done from one employee's perspective, rather it is recommended at the same time from two points of view, namely the perspective of the leaders / top management / manager and also the point of view of the employees themselves.

Keywords: Individual Characteristics; Intrinsic Motivation; Innovative Behaviour; Employee Performance.
\end{abstract}

\begin{abstract}
Abstrak
Tujuan dari penelitian ini adalah untuk menyelidiki efek dari karakteristik individu, Motivasi intrinsik pada perilaku inovatif dan kinerja karyawan, dan efeknya perilaku inovatif pada kinerja karyawan. Penelitian dilakukan di perbankan perusahaan, ukuran sampel adalah sekitar 200 karyawan. Metode analisis data yang digunakan dalam hal ini penelitian adalah metode analisis kuantitatif dimana metode analisis data kuantitatif adalah metode analisis dalam bentuk angka dan perhitungan menggunakan metode statistik. Dalam menyederhanakan proses analisis, akan digunakan Structural Equations Modeling (SEM). Menurut analisis, itu disimpulkan sebagai berikut: karakteristik individu memiliki efek positif pada perilaku inovatif; motivasi intrinsik memiliki efek positif pada perilaku inovatif; karakteristik individu berpengaruh positif terhadap kinerja karyawan. Motivasi intrinsik berpengaruh negatif terhadap kinerja karyawan dan perilaku inovatif berpengaruh positif terhadap kinerja karyawan. Hasil penelitian ini dan keterbatasan yang ditemukan sebagai sumber ide dan masukan untuk pengembangan penelitian ini di masa depan, perluasan yang
\end{abstract}


disarankan dari penelitian ini meliputi: Penelitian di masa depan tidak hanya dilakukan dari perspektif satu karyawan, melainkan direkomendasikan pada saat yang sama dari dua sudut pandang, yaitu perspektif pemimpin / manajemen puncak / manajer dan juga sudut pandang karyawan itu sendiri

Kata Kunci: Karakteristik Individu, Motivasi Intrinsik, Perilaku Inovatif, Kinerja Karyawan

How to Cite: Yuniawan, A., Filatrovi, E. W., \& Attig, K. (2020). Finding Ways to Improve Employee Performance in Banking Sector. Media Ekonomi dan Manajemen, 35(2), 218-229. doi: http://dx.doi.org/10.24856/mem.v35i2.1521.

\section{INTRODUCTION}

Global competition requires each bank to be able to optimize and manage human resources. Human resource management cannot be separated from the factors of employees who are expected to perform their best to achieve the bank's objectives. These banks face challenges in being able to improve the quality of human resources so they have special expertise so they can compete with the business world. Human resources are a very important factor in a bank, both large and small scale banks. In large scale banks, human resources are seen as a very decisive element in the business develop1,ment process, the role of human resources is becoming increasingly important (Tadjudin, 1995). Human resources occupy the most strategic position among other resources, so that the performance of human resources will affect how the bank's overall performance.

$\mathrm{HR}$ is the most important element, as revealed by Hardyansyah (2012) that humans as workers in organizations have an important role in achieving goals and providing good services for organizations and society. Employees are the most important factor in production, because they must have the will and ability to perform tasks that are assigned by the company.

According to Yuniarti and Fadila (2008), some experts argue that the key to a company's competitive advantage is the quality of the human resources that are in it. The success of a company, both large and small companies, is very dependent on its ability to develop and manage human resources within the company. Human resources are considered as a factor that greatly influences the company in achieving its objectives. Human resources (HR) is a very important asset for an organization, which is the focus of the organization to create value that aims to maintain its existence in a competitive environment. It is not wrong if in facing global challenges, the agenda for competition is human resources (Siagian, 2004). Competent HR is an HR that is able to maintain and be able to advance the company into a superior company among other similar companies and able to become a going concern company. Rohman (2013) research results, showed that individual characteristics variables have a significant influence on employee performance in the Office of Family Planning and Women's Empowerment in Donggala Regency. Likewise, the results of research by Gede and Lawanson (2011) show that individual characteristics can improve the performance of human resources.

Cheng (2011) research results show that intrinsic motivation can improve innovative behavior. Likewise, the results of Ratnasari's research (2014), showed that intrinsic motivation has a positive and significant effect on innovative behavior. Kiruja and Mukuru (2013) research results show that intrinsic motivation will improve the performance of human resources. However, different from Dur's research (2014) shows that intrinsic motivation is not significant to the performance of human resources. The results of research by Froiland et al., (2012) show that increasing innovative behavior can 
improve the performance of human resources. However, different from Loof and Heshmati's (2002) research shows that innovative behavior is not significant to human resource performance

In achieving company targets, the company must also be supported by human resources who can be considered competent and experts in their respective fields of work. Employees who are able to work well have high work motivation and have an innovative spirit at work. The performance of the employees of the banking in central java, which continued to decline over the past two years, is the source of the problems in this study. The difference in the results of previous studies and the phenomenon of employee performance that has not been optimal, the formulation of the problem in this study is how employee performance can be improved and whether there is an influence with individual characteristics, intrinsic motivation and innovative behavior of employees.

This study aims to look at employee performance through individual characteristics and intrinsic motivation, especially in terms of innovative employee behavior in banking companies in Central Java.

\section{LITERATURE REVIEW}

\section{Employee Performance}

Employee job performance has always been an important concern for managers of organisations (Kelidbari, et al, 2011). According to Lee, et-al, (2011), in a study titled - The effects of internal marketing, job satisfaction and service attitude on job performance among hightech has always been regarded as an important item in organizational management\| defined job performance as workers' total performance in meeting the anticipated worth and achievement of tasks under the procedure and time requirements of the organization. Similarly Liao et-al, (2012), define job performance as the standard for advancements, redundancy, rewards, punishments, reviews and salary changes. It also satisfies the needs for employees to realize themselves. Ahmad and Shahzam (2011), also argue that employee performance symbolises the broad belief of the personnel about their behaviour and contributions towards the achievement of the organization.

\section{Individual Characteristics}

Rohman (2013), characteristics are traits that are able to improve the quality of life, while individual characteristics are characteristics that show a person's differences about motivation, initiative, ability to remain rigid in facing tasks to the point or solve problems or how to adjust changes that are closely related to the environment which affects individual performance.

\section{Intrinsic Motivation}

Etymologically, Winardi (2008) explains the purpose of Latin, which is movere which means to move (to move). This word motivation in English becomes motivation which means motivation, motive for arising or something that is interesting or causes motivation. Furthermore Winardi (2008) suggests that a person's motivation depends on the motives of his motives. Winardi (2008) explains the motives sometimes representing people as needs, desires, drives that arise in a person. Motives are directed toward goals that can arise in the conscious state or in the unconscious condition.

\section{Innovative Behavior}

Human resources is one of the most important factors in a bank, because the quality of the bank it self is highly dependent on the quality of human resources as human resources and service providers in a bank. Basicly, to get innovative human resources in accordance with needs, a strategy is needed in managing human resources, good human resource management will provide progress for banks, especially in dealing with situations 
and conditions that are always changing and developing (Megan,et.al.,2007).

\section{Hypothesis Development}

Sugijanto (2011), individual characteristics are behaviors or characters that exist in an employee both positive and negative. Individual characteristics are the characters that are owned by each person who is different from one person to another. The characteristics and behavior of people in a bank are the core of the bank. Banks must be able to encourage their employees to work innovatively so that they can survive in the long run. The research results of Patterson, et al (2014) show that individual characteristics can improve innovative behavior.

Based on the description above, the hypothesis proposed is:

H1: When individual characteristics increase, innovative behavior increases.

Cheng (2011) research results show that intrinsic motivation can improve innovative behavior. Likewise, the results of Ratnasari's research (2014), showed that intrinsic motivation has a positive and significant effect on innovative behavior.

Based on the description above, the hypothesis proposed is:

$\mathrm{H} 2$ : When intrinsic motivation increases, innovative behavior increases.

Rohman (2013) research results, showed that individual characteristics variables have a significant influence on employee performance in the Office of Family Planning and Women's Empowerment in Donggala Regency. Likewise, the results of research by Gede and Lawanson (2011) show that individual characteristics can improve the performance of human resources.
Based on the description above, the hypothesis proposed is:

H3: When individual characteristics increase, employee performance increases.

Efforts to improve the performance of human resources is not an easy job, because the performance of human resources is influenced by many factors including skills, work environment and motivation of leaders and human resource work discipline. Explicitly the performance of the most dominant human resources is caused by one's mental readiness to refer to oneself and achievement in order to obtain everything expected (Froiland et al., 2012). The results of research from Kiruja and Mukuru (2013) indicate that intrinsic motivation will improve the performance of human resources. Likewise, the results of Ratnasari's research (2014), showed that intrinsic motivation has a positive and significant effect on the performance of human resources. Based on the description above, the hypothesis proposed is:

H4: When intrinsic motivation increases, employee performance increases.

Banks need to improve innovative behavior by frequently holding training for employees both soft skills and hard skills. With banks often holding trainings, this will help employees to become more trained and accustomed to expressing their ideas and be able to fight for new ideas that are planned and carried out so that employee performance increases (Putri and Budiastuti, 2014). Meanwhile, according to Bysted (2013) there is a positive influence of innovative behavior on the performance of human resources. The results of research by Froiland et al., (2012) show that increasing innovative behavior can improve the performance of human resources. 
Based on the description above, the hypothesis proposed is:

H5: When innovative behavior increases, employee performance increases.

\section{Research Models}

The framework models of research is illustrated in Figure 1.

\section{RESEARCH METODS}

\section{Types of Research}

This research is quantitative explanatory research based on theories or hypotheses to ntest a phenomenon that occurs (Cooper and Schindler, 2006). Primary data collection techniques use questionnaires directly to respondent.

\section{Sample}

The sample became the object of research is employee in Banking Companies Central Java as many as 200 employee who have worked for 2 years.

\section{Reliability and Validity Test Analysis}

Reliability test to test whether the questionnaire is still worthwhile to use. To see eligibility can be seen through Cronbach alpha values, bilakoefisien alpha (a) greater than 0.6 and less than 0.6 if a show is no consistency (Singgih, 2000)
.Validity test to see whether respondents can understand the questions made, A measuring instrument is said to be valid if the corrected item total correlation greater than or equal to 0.41 (Singgih 2000).

\section{Data Analysis Method}

Methods of data analysis used in this study is a quantitative analysis method where quantitative data analysis method is a method of analysis in the form of figures and calculations using statistical methods.

The tools used to process the data in this study is SEM (Structural Equation Model) which is operated by AMOS (Analysis of Moment Structure). In Ferdinand (2014) described, there are seven steps to be taken when using Structural Equation Model (SEM), namely: (1) Development of a model-based theory, (2) Development of flow charts to show causality, (3) Conversion flowcharts in series and structural equation model specification measurement, (4) Selection of input matrix and the estimation technique on a model built, (5) Assess the problem identification, (6) Evaluation criteria Goodness-of-fit, and (7) interpretation and modification of the model.

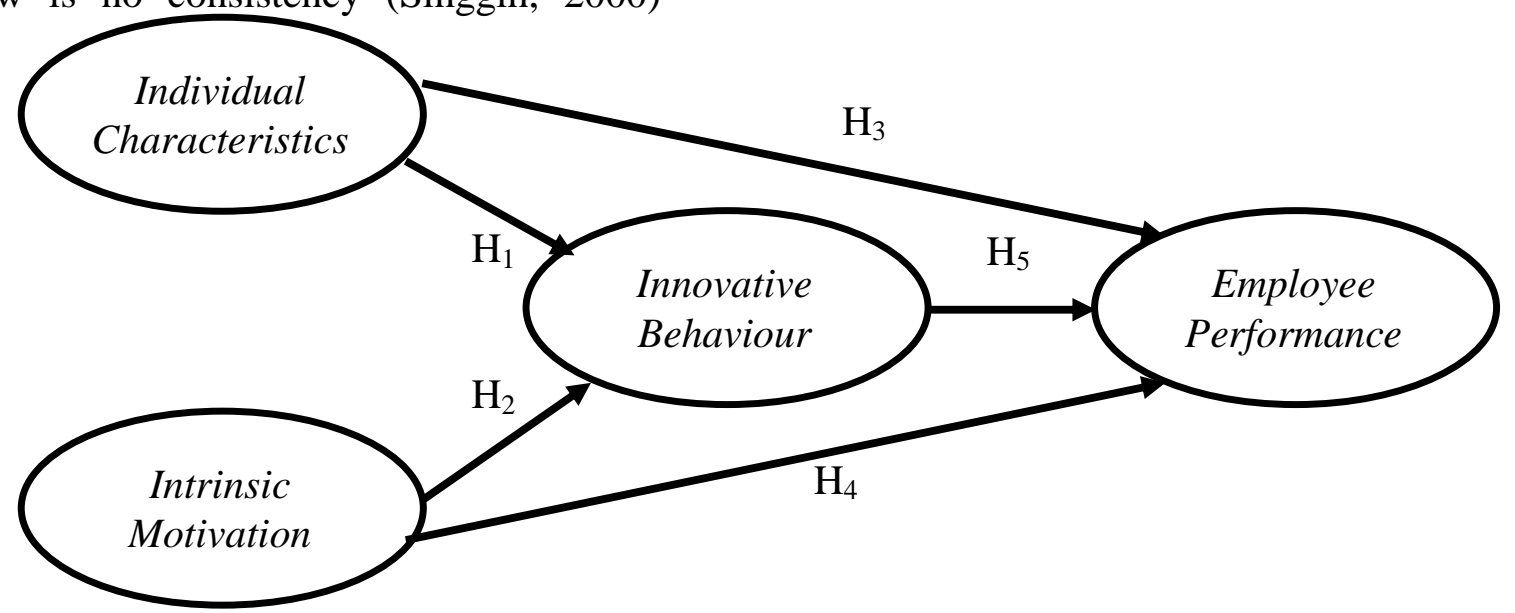

Figure 1. Research Framework 
Tabel 1. Operational Definitions of Variables and Indicators

\begin{tabular}{|c|c|c|c|}
\hline No & Variable & Indicator & Reference \\
\hline \multirow[t]{4}{*}{1.} & Employee & 1. Quality. & Masud (2004) \\
\hline & Performances & 2. Quantity. & \\
\hline & & 3. Knowledge. & \\
\hline & & 4. Supervision needs & \\
\hline \multirow[t]{4}{*}{2.} & Individual & 1. Able to manage work time effectively & Goodard (2001) \\
\hline & Characteristics & 2. Get the job done faster & \\
\hline & & 3. Actively giving thoughts at meetings & \\
\hline & & 4. The ability to make presentations & \\
\hline \multirow[t]{4}{*}{3.} & Intrinsic Motivation & 1. Care about work & Mas’ud (2004) \\
\hline & & 2. Fun work & \\
\hline & & 3. Provide learning opportunities & \\
\hline & & 4. Attract interest & \\
\hline \multirow[t]{4}{*}{4.} & Innovative Behavior & 1. Share new knowledge & Bysted, (2013) \\
\hline & & 2. Share new information about work & \\
\hline & & 3. Attention to coworkers & \\
\hline & & 4.Share stories with coworkers & \\
\hline
\end{tabular}

\section{RESULT AND DISCUSSION}

In this section will explain the descriptive data obtained from respondents. Descriptive data are presented research that can be seen the profile of the research data and the relationships that exist between the variables used in the research (Hair et al, 1995 in Ferdinand, 2002)).

Table 1 showed that female respondents a majority of respondents ie $51.50 \%$ of the total of 200 respondents participated in the study.

The next test is to see the level of normality of the data used in this study. This test is to examine the value of skewness of the data used, if the value of $\mathrm{CR}$ in the data skewness in the range between more or less than 2.58 at the 0.01 level. Results of testing the normality of the data shown in Table 2.

From the data processing are shown in Table 3 shows that the there are no $\mathrm{CR}$ values for skewness which is outside the range of more or less than 2.58. Thus, the use of research data which meets the requirements of the normality of the data, or it can be said that the research data was normally distributed.

Evaluation of the multivariate outliers need dilakuakan because although the data analyzed showed no outliers on the level of univariate, but the observations that may be outliers when it is combined, Distance Mahalonobis for each observation can be calculated and will show the distance of an observation of the average of all the variables in a multidimensional space (Hair, et al 1995; Norusis, 1994; Tabacnick and Fidel, 1996 in Ferdinand, 2002). To calculate the distance mahalonobis chi-square value based on the degree by 16 (indicator) at the level of $\mathrm{p}<0.001$ was $\pi 2(16,0.001)=37.697$ (based on the distribution table $\pi 2$ ). From the results of data processing can be seen that the maximum distance mahalainobis 35.299. So in this analysis did not reveal any outliers.

Subsequent analysis is the analysis of Structural Equation Model (SEM) as a full model, after analysis of the level of the indicators unidimensionalitas forming latent variables tested by confirmatory factor analysis. Analysis of the data processing at the stage of full model SEM carried out to test the suitability and statistical tests (Figure 2).

For a statistical test to the relationship between variables that will be used as a basis for answering the research hypotheses have been proposed. Feasibility model testing results SEM analysis can be described in Table 4. Statistical test results with SEM processing done by looking at a 
significance level of relationships between variables revealed through the value of probability (p) and and Critical Ratio (CR) of each relationship between variables.

\section{Hypothesis Result}

The hypothesis of this study five hypotheses. Based on Table 5, the conclusions of the five hypotheses are as follows:

The results of testing individual characteristics for innovative behavior can be concluded that individual characteristics have a positive effect on innovative behavior. The estimation parameter for testing the effect of individual characteristics on innovative behavior shows a $\mathrm{CR}$ value of 2.648 and with a probability of 0.008 . Both of the values obtained are eligible for $\mathrm{H} 1$ acceptance.

The results of testing intrinsic motivation for Innovative Behavior, it can be concluded that intrinsic motivation has a positive effect on innovative behavior. The estimated parameters for testing the effect of Intrinsic Motivation on Innovative Behavior show a $C R$ value of 2.046 and with a probability of 0.041 . Both values are obtained to meet the requirements for $\mathrm{H} 2$ acceptance, namely a CR value of 2.046, which is greater than 1.96 and a probability of 0.041 , which is less than 0.05 . Thus it can be concluded that intrinsic motivation has a positive effect on innovative behavior.

The results of testing individual characteristics for employee performance can be concluded that individual characteristics have a positive effect on employee performance. Estimation parameters for testing Individual Characteristics of Em- ployee Performance show a CR value of 2.594 of and with a probability of 0.009 . Both values are obtained to meet the requirements for $\mathrm{H} 3$ acceptance, namely a $\mathrm{CR}$ value of 2.594 which is greater than 1.96 and a probability of 0.009 which is smaller than 0.05 . Thus it can be concluded that individual characteristics have a positive effect on employee performance.

The results of testing Intrinsic Motivation for Employee Performance, it can be concluded that intrinsic motivation has no negative effect on employee performance. Discussion of Hypothesis Testing 4. The estimated parameters for testing Intrinsic Motivation on Employee Performance show a CR -0.008 value of and with a probability of 0.993 . The two values obtained did not meet the requirements for $\mathrm{H} 4$ acceptance, namely a CR value of 0.008 which was smaller than 1.96 and a probability of 0.993 that was greater than 0.05 . Thus it can be concluded that intrinsic motivation does not negatively affect employee performance.

The results of testing Innovative Behavior on Employee Performance can be concluded Innovative Behavior has a positive effect on Employee Performance. The estimated parameters for testing the effect of Innovative Behavior on Employee Performance show a CR value of 2.333 and with a probability of 0.019 . Both of these values are obtained to meet the requirements for $\mathrm{H} 5$ acceptance, namely a $\mathrm{CR}$ value of 2.333 which is greater than 1.96 and a probability of 0.019 that is smaller than 0.05. Thus it can be concluded that Innovative Behavior has a positive effect on Employee Performance.

Table 1. Sample Characteristics

\begin{tabular}{|c|c|c|c|}
\hline \multicolumn{2}{|c|}{ Demographics Characteristics } & \multirow{2}{*}{$\frac{\text { Number Response }}{68}$} & \multirow{2}{*}{$\begin{array}{r}\text { Percentage } \\
0.34\end{array}$} \\
\hline Age & $<30$ & & \\
\hline & $31-40$ & 73 & 0.365 \\
\hline & $41-50$ & 35 & 0.175 \\
\hline & $>51$ & 24 & 0.12 \\
\hline \multirow[t]{2}{*}{ Gender } & Male & 97 & 0.485 \\
\hline & Female & 103 & 0.515 \\
\hline
\end{tabular}

Sources: Primary data are processed, 2019 
Table 2. Normality Data

\begin{tabular}{|c|c|c|c|c|c|c|}
\hline Variable & Min & Max & Skew & cr & kurtosis & cr \\
\hline $\mathrm{x} 13$ & 1.000 & 5.000 & 0.052 & 0.233 & -0.213 & -0.477 \\
\hline x14 & 1.000 & 5.000 & -0.135 & -0.605 & -0.136 & -0.305 \\
\hline x 15 & 1.000 & 5.000 & -0.232 & -1.037 & -0.034 & -0.075 \\
\hline x16 & 1.000 & 5.000 & -0.183 & -0.820 & -0.169 & -0.377 \\
\hline x 8 & 1.000 & 5.000 & -0.605 & -2.705 & 0.271 & 0.607 \\
\hline $\mathrm{x} 7$ & 1.000 & 5.000 & -0.339 & -1.515 & -0.121 & -0.271 \\
\hline x6 & 2.000 & 5.000 & 0.085 & 0.381 & -0.961 & -2.149 \\
\hline $\mathrm{x} 5$ & 2.000 & 5.000 & 0.119 & 0.532 & -0.730 & -1.632 \\
\hline $\mathrm{x} 12$ & 1.000 & 5.000 & -0.211 & -0.946 & 0.160 & 0.358 \\
\hline $\mathrm{x} 11$ & 1.000 & 5.000 & -0.043 & -0.190 & -0.478 & -1.069 \\
\hline $\mathrm{x} 10$ & 1.000 & 5.000 & -0.128 & -0.574 & -0.591 & -1.322 \\
\hline x9 & 1.000 & 5.000 & -0.181 & -0.809 & -0.446 & -0.996 \\
\hline x4 & 1.000 & 5.000 & -0.176 & -0.785 & -.0790 & -1.767 \\
\hline $\mathrm{x} 3$ & 1.000 & 5.000 & 0.285 & 1.273 & -0.462 & -1.032 \\
\hline $\mathrm{x} 2$ & 1.000 & 5.000 & -0.260 & -1.161 & -0.466 & -1.041 \\
\hline $\mathrm{x} 1$ & 2.000 & 5.000 & 0.352 & 1.576 & -0.413 & -0.924 \\
\hline
\end{tabular}

Table 3. Multivariate Outliers

\begin{tabular}{r|r|r|r}
\hline Observation number & D-squared Mahalanobis & p1 & p2 \\
\hline 7 & 34.339 & 0.003 & 0.263 \\
30 & 29.539 & 0.014 & 0.398 \\
99 & 27.231 & 0.027 & 0.506 \\
---- & --- & --- & --- \\
---- & --- & --- & --- \\
10 & 6.871 & 0.961 & 0.249 \\
87 & 6.540 & 0.969 & 0.183 \\
5 & 5.851 & 0.982 & 0.165 \\
\hline
\end{tabular}

Source: Research data are processed, 2019 


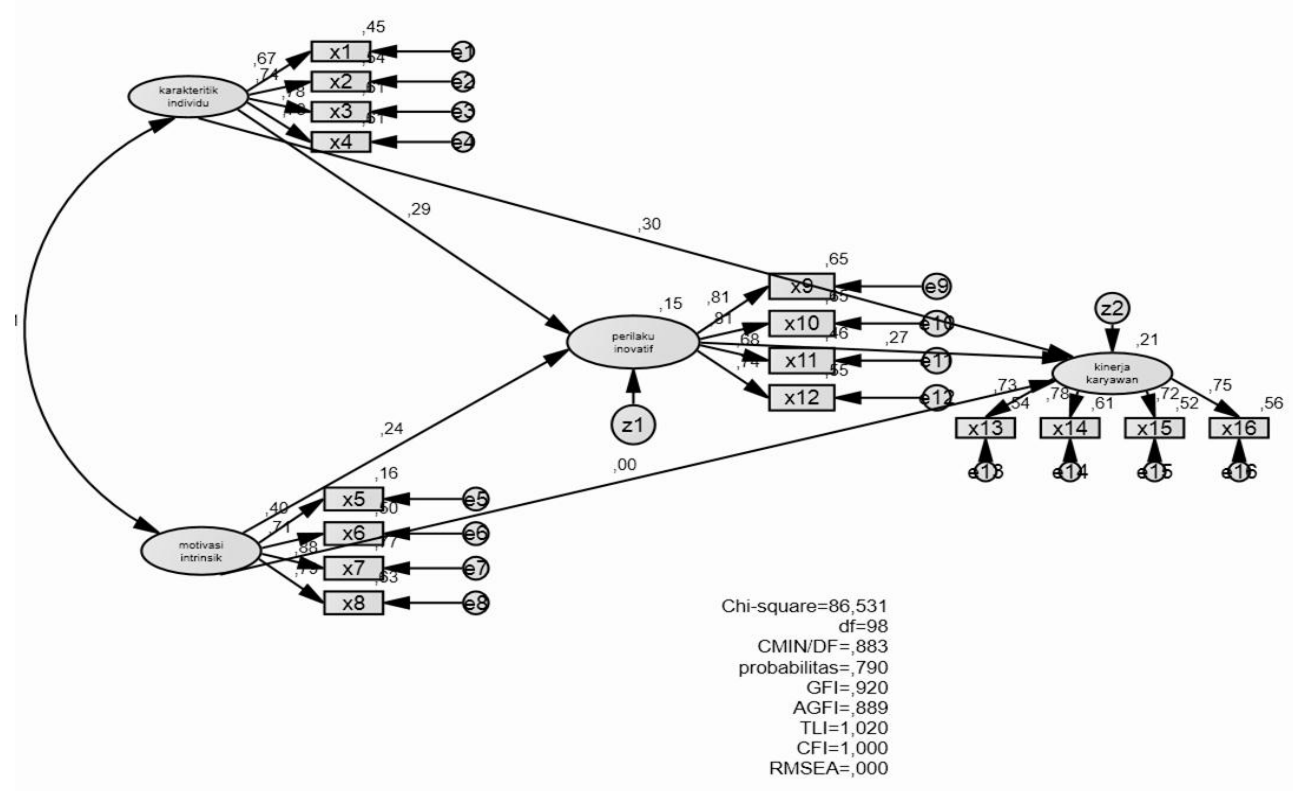

Figure 2. Full Model SEM AMOS

Table 4. Feasibility Model Testing Results SEM Analysis

\begin{tabular}{lcccc}
\hline Goodness of Fit Index & Cut-off Value & Results Analysis & evaluation Model \\
\hline Chi - Square & $<122.107 ;$ df 98 & 86.531 & Fit \\
Probability & $\geq 0.05$ & 0.790 & Fit \\
RMSEA & $\leq 0.08$ & 0,001 & Fit \\
GFI & $\geq 0.90$ & 0.920 & Fit \\
AGFI & $\geq 0.90$ & 0.889 & Marginal \\
CMIN / df & $\leq 2.00$ & 0.883 & Fit \\
TLI & $\geq 0.95$ & 1.020 & Fit \\
CFI & $\geq 0.95$ & 1.000 & Fit \\
\hline
\end{tabular}

Source: Research data are processed, 2019

Table 5. Standardized Regression Weight

\begin{tabular}{|c|c|c|c|c|c|c|c|}
\hline \multicolumn{3}{|c|}{ Variable } & \multirow{2}{*}{$\begin{array}{r}\text { estimate } \\
0.374\end{array}$} & \multirow{2}{*}{$\frac{\text { SE }}{0.141}$} & \multirow{2}{*}{$\begin{array}{l}\text { CR } \\
2.648\end{array}$} & \multirow{2}{*}{$\begin{array}{c}\mathbf{P} \\
0.008\end{array}$} & \multirow{2}{*}{$\begin{array}{c}\begin{array}{c}\text { Infor- } \\
\text { mation }\end{array} \\
\text { Sig }\end{array}$} \\
\hline Innovative Behavior & $<--$ & $\begin{array}{l}\text { Individual } \\
\text { Characteristics }\end{array}$ & & & & & \\
\hline Innovative Behavior & $<--$ & $\begin{array}{l}\text { Intrinsic } \\
\text { Motivation }\end{array}$ & 0.487 & 0.238 & 2.046 & 0.041 & Sig \\
\hline $\begin{array}{l}\text { Employee } \\
\text { Performances }\end{array}$ & $<--$ & $\begin{array}{l}\text { Innovative } \\
\text { Behavior }\end{array}$ & 0.232 & 0.099 & 2.337 & 0.019 & Sig \\
\hline $\begin{array}{l}\text { Employee } \\
\text { Performances }\end{array}$ & $<---$ & $\begin{array}{l}\text { Individual } \\
\text { Characteristics }\end{array}$ & 0.334 & 0.129 & 2.594 & 0.009 & Sig \\
\hline $\begin{array}{l}\text { Employee } \\
\text { Performances }\end{array}$ & $<--$ & $\begin{array}{l}\text { Intrinsic } \\
\text { Motivation }\end{array}$ & -0.002 & 0.185 & -0.008 & 0.993 & No Sig \\
\hline
\end{tabular}

Source: Research data are processed, 2019 


\section{DISCUSSION}

Once the important role of $\mathrm{HR}$ in determine the company's success, then the organization must be able to realize the desires and employee needs through giving motivation so that it can achieve that performance high. Every manager needs to predict skills development efforts and managerial ability to provide motivation to his subordinates. The manager has responsibilities for helping and influencing behavior conducted by subordinates so they can carry out the task effectively and efficiently. Therefore the manager's success motivates his subordinates depends on how the manager understands the motives/interests of its employees. In this case, the company not only expect employees to be capable, capable and skilled, but most importantly they want work hard and desire to achieve results maximum performance.

In a company or organization, every individuals strive to realize the shared goals by utilizing the whole existing company's or organization's resources. Basically the goal is to reach the company target in order to create continuous benefit and create prosperity for its members. Employees at the company are the resource which largely determines the achievement of company goals. Achievement of company goals is not easy because it requires a strategy which is supported by good human resources, intrinsic motivation, innovative behavior and good employee performance.

These four variables in this study have very important roles in the company. The individual characteristic variable has the highest indicator's score. The ability to manage employee's works is related to the way employees usually done their work in a well and efficient manner. Intrinsic motivation variable has the highest indicator's score that is concerned with employees' work. This results shows the concern for what is being done and implies for what employees must maintain and concern at work. The innovative behavioral variable has the highest indicator's score of sharing new know-ledge. This implies for employees to share new knowledge and for the company to update banking knowledge dynamically. Employee performance also has the highest indicator's score. The quantity related to employees' work and they must pay more attention to it for their daily work.

\section{CONCLUSION AND RECOMENDA- TION}

The purpose of the research is to find answers to the research problems raised in this study are: "how to improve employee performance?". The results of this study prove and provide conclusions to answer the research problem briefly producing two (2) basic processes to improve employee performance. First, to get innovative behavior in influencing employee performance is to see the magnitude of individual characteristics. Second, to get innovative behavior in influencing employyee performance is to see the amount of intrinsic motivation.Some of the limitations of research that can be drawn from this study are as follows: The study only analyzes employee performance problems from one dimension or one point of view, that is, from the point of view of the employee, but does not explore from other perspectives such as company officials / top management or from the point of view of managers who supervise the employees so that it can produce a research result that better illustrates the many dimensions of the factors that cause an increase in employee performance.

Manager must create / foster innovative behavior in improving employee performance, both from increasing intrinsic motivation and from individual characteristics and high solidarity between colleagues and a comfortable atmosphere in the office environment. In addition, leaders are required to always give appreciation to all employees, relationships need each other and act in accordance with 
employee expectations. Manager always need good employees and have high performance in carrying out tasks in order to achieve the acceptance targets that have been charged from the company. If there is a decrease in performance it can have a negative impact on the company with an indication of not achieving the target.

The results of this study and the limitations found to be a source of ideas and input for the development of this study in the future, the suggested expansion of this research include: Future research is not only done from one employee's perspective, rather it is recommended at the same time from two points of view, namely the perspective of the leaders/top management/ manager and also the point of view of the employees themselves.

\section{REFERENCES}

Ahmad, S., \& Shahzad, K. (2011). HRM and employee performance: A case of university teachers of Azad Jammu and Kashmir (AJK) in Pakistan. African Journal of Business Management, 5(13), 5249-5253.

Bysted, R. (2013). Innovative employee behavior. European Journal of Innovative Management, 16(3), 268284.

Cheng H. T. (2011). Innovative Behaviors between Employment Modes in Knowledge Intensive Organizations, Cheng Shiu University, Taiwan.

Cooper, D. R., \& Pamela, S. S. (2006). Metode Riset Bisnis. Jakarta: PT Media Global Edukasi

Dur, R., \& Zoutenbier, R. (2014) Instrinsic motivation of public sector employees: Evidence for Germany. Iza Discussion Paper.
Endres, M. L., Endres, S. P., Chowdhury, S. K., \& Alam, I. (2007). Tacit knowledge sharing, self-efficacy theory, and application to the open source community. Journal of knowledge management. 92-103.

Ferdinand, A. (2014). Metode Penelitian Manajemen: Pedoman Penelitian untuk Skripsi, Tesis dan Disertasi Ilmu Manajemen. Semarang: Badan Penerbit Universitas Diponegoro.

Froiland, N. D., \& Gassmann, O. (2012). Innovative Work Behavior: The Roles of Employee Expectations and Effects on Job Performance. European Journal of Innovative Management.

Gede, N. T., \& Lawanson, O. A. (2011). Employees Characteristics and Job Performance of Staff of The Bayelsa State Ministry of Education, Dept of Educational Management, Faculty of Education, University of Port Harcourt, Nigeria.

Goodard, J.(2001), High performance and the transformation of work The implications of alternative work practices for the experience an outcome of works, ProQuest.

Hardyansyah, A., \& Yanwar, R. P. (2012). Pengaruh Etos Kerja Terhadap Kinerja Karyawan PT. AE. Jurnal Al- Azhar Indonesia Seri Humaniora,3(2), 150-158.

Kelidbari, H. R., Dizgah, M. R., \& Yusefi, A. (2011). The relationship between organization commitment and job performance of employees of Guilan Province social security organization. Interdisciplinary Journal of Contemporary Research in Business, 3(6), 555.

Kiruja, E.K., \& Mukuru, E. (2013). Effect of motivation on employee performance in Public Middle Level Technical Training Institutions in Kenya. International Journal of Advances in Managements and Economics, 2(4), 73-82. 
Liao, C. W., Lu, C. Y., Huang, C. K., \& Chiang, T. L. (2012). Work values, work attitude and job performance of green energy industry employees in Taiwan. African Journal of Business Management, 6(15), 5299-5318.

Lööf, H., \& Heshmati, A. (2002). Knowledge capital and performance heterogeneity:: A firm-level innovation study. International Journal of Production Economics, 76(1), 6185.

Mas'ud, F. (2014). Survei Diagnosis Organisasional, Semarang: BP Universitas Diponegoro.

Patterson, F., Kerrin; M., \& Roissard, G. G. (2014). Characteristics and behavior of innovative people in organizations. Literature Review. A Paper Prepared forNESTA Policy and Research Unit (NPRU).

Putri, A.P., \& Astuti, B. (2014). Analysis of Customer Sociability \& Total Service Experience towards Word of Mouth on Erha Clinic Consumer. Proceeding of Collaborative Symposium of UKM-GSB \& FE UII.

Ratnasari, M. G. Y. (2014). Peningkatan Kinerja Sumber Daya Manusia Melalui Kepemimpinan Transformasional, Motivasi Intrinsik Serta Perilaku Inovatif (Doctoral dissertation, Fakultas Ekonomi UNISSULA).

Rohman, A. (2013). Pengaruh Karakteristik Individu, Motivasi dan Budaya Kerja Terhadap Kinerja Pegawai pada Badan Keluarga Berencana dan Pemberdayaan Perempuan Kabupaten Donggala, Universitas Tadulako. Katalogis, 1, 76-86.
Santoso, S. (2000). Buku latihan SPSS statistik parametrik. Penerbit Elex Media Komputindo.

Sugijanto, H. (2011). Pengaruh antara Karakteristik Individu dan Karakteristik Pekerjaan terhadap Motivasi dan Kepuasan Kerja pada SMA Swasta di Surabaya. Skripsi. Surabaya: FE UKWMS.

Tadjudin (1995). Studi empiris faktorfaktor yang mempengaruhi kinerja, Jurnal Siasat Bisnis, 6(1),

Winardi, J. (2008). Motivasi dan Pemotivasian dalam Manajemen. Jakarta: PT. Raja Grafindo Persada. 